\title{
Cross-cultural adaptation of the Sport Anxiety Scale-2 (SAS-2) for the Brazilian context
}

\author{
Adaptação transcultural da Sport Anxiety Scale-2 (SAS-2) para o contexto \\ brasileiro
}

Viviane Vedovato Silva-Rocha, ${ }^{1}$ Flávia de Lima Osório ${ }^{2}$

\begin{abstract}
Objective: To present the process of cross-cultural adaptation of the Sport Anxiety Scale-2 (SAS-2) for the Brazilian context.

Method: The following stages were used: translation into Brazilian Portuguese by independent translators, elaboration of a synthesis version, back-translation, evaluation by experts and pretest with target population.

Results: All the stages of cross-cultural adaptation were completed, and in the majority of items evaluated, good concordance between experts was obtained ( $\geq 80 \%)$. Suggested adjustments were compiled into the consensus version by the two authors, with the resulting material being considered adequate in the pretest (and thus no further changes were needed). Termed as "Escala de Ansiedade Esportiva-2," the final version was considered by the main author of the original scale as an official version in Brazilian Portuguese.

Conclusions: In view of the fulfilment of all steps suggested for the cross-cultural adaptation process, the SAS-2 is now available in Brazilian Portuguese to be tested for its psychometric qualities.
\end{abstract}

Keywords: Competitive anxiety, scales, cross-cultural adaptation, sports.

\section{Resumo}

Objetivo: Apresentar o processo de adaptação transcultural da Sport Anxiety Scale-2 (SAS-2) para o contexto brasileiro.

Método: Os seguintes estágios foram utilizados: tradução para o português do Brasil por tradutores independentes, elaboração da versão síntese, retrotradução, avaliação de equivalência por especialistas e pré-teste na população-alvo.

Resultados: Todos os estágios do processo de adaptação transcultural foram respeitados, e, na maioria das estruturas avaliadas, obteve-se porcentagem de concordância satisfatória entre os especialistas ( $\geq 80 \%$ ). Os ajustes sugeridos foram compilados pelas duas autoras na versão de consenso, e o material foi considerado adequado no pré-teste, não havendo necessidade de mais modificações. Nomeada "Escala de Ansiedade Esportiva-2", foi considerada pelo autor principal da escala original como a versão oficial em português do Brasil.

Conclusão: Mediante cumprimento de todas as etapas sugeridas para o processo de adaptação transcultural, a SAS-2 está disponível em português brasileiro para ser testada quanto às suas qualidades psicométricas.

Descritores: ansiedade competitiva; escalas; adaptação transcultural; esporte.

\footnotetext{
${ }^{1}$ Programa de Pós-Graduação em Saúde Mental, Departamento de Neurociências e Ciências do Comportamento, Faculdade de Medicina de Ribeirão Preto, Universidade de São Paulo, São Paulo, SP, Brazil. ${ }^{2}$ Departamento de Neurociências e Ciências do Comportamento, Faculdade de Medicina de Ribeirão Preto, USP, São Paulo, SP, Brazil.

Submitted Mar 06 2017, accepted for publication May 152017.

Suggested citation: Silva-Rocha VV, Osório FL. Cross-cultural adaptation of the Sport Anxiety Scale-2 (SAS-2) for the Brazilian context. Trends Psychiatry Psychother. 2017;39(3):202-206. http://dx.doi.org/10.1590/2237-6089-2017-0027
} 


\section{Introduction}

Sports practices often involve situations in which athletes experience emotional vulnerability, with emphasis on competitions. In this context, it is common to experience symptoms such as muscle tension, tachycardia, flushing, trembling and sweating, as well as concerns about self-demand, performance, thirdparty assessment, social comparisons and expectations by coaches, teammates, family and fans. ${ }^{1-4}$

This set of symptoms, called competitive anxiety, ${ }^{1}$ can be experienced transiently in the state condition and/or persistently in the trait condition, generally with the latter facilitating the former. Depending on the frequency, the intensity and the way how the athlete interprets and reacts to this emotion, negative implications can be observed, such as energy loss, poor coordination, cardiovascular changes, impairment in attention and concentration, decreased decision-making ability, increased interpersonal conflicts, abandonment of the sports practice, among others..$^{2,5}$

For an early identification of pathological features and development of interventions to prevent or minimize damages to the athlete's career, thus favoring a more effective guidance of this emotion in order to maximizer his/her performance, a comprehensive assessment process becomes necessary. In this process, the use of measurement scales plays a unique role in the tracking and identification of symptoms.

In the literature, one can find the Competitive State Anxiety Inventory-2 (CSAI- 2$),{ }^{6}$ including its revised version (CSAI-2R), ${ }^{7}$ as well as the Sport Competition Anxiety Test (SCAT) ${ }^{1}$ and the Sport Anxiety Scale-2 $\left(\right.$ SAS-2) ${ }^{8}$ for the assessment of competitive trait anxiety. Available in different languages, only CSAI-2/CSAI-2 ${ }^{9}$ and SCAT $^{10}$ have been cross-culturally adapted to the Brazilian context.

The SAS-2, object of the present study, was originally developed in English. It is a modified version of the Sport Anxiety Scale (SAS) aiming to assess trait anxiety experienced by athletes from 9 years old on before and during competitions. Consisting of 15 items divided into three factors (somatic anxiety, preoccupation, and concentration disruption), its score is based on a 4-point Likert scale ( $1=$ not at all, to $4=$ extremely), ranging from 5 to 20 points in total. Psychometric indices are satisfactory regarding construct validity (comparative fit index $[\mathrm{CFI}]=0.95-0.97$; non-normed fit index [NNFI] $=0.95-0.96$; root-mean square error of approximation [RMSEA] =0.05-0.065), internal consistency ( $a \geq$ $0.84)$, and test-retest reliability $(\geq 0.76) .{ }^{8}$ The SAS-2 has been adapted and validated to Dutch, ${ }^{11}$ Spanish, ${ }^{12}$ and Portuguese of Portugal. ${ }^{13}$
Considering that the SAS-2 has been widely used by studies assessing competitive trait anxiety due to its multidimensionality (differently from the SCAT, which does not distinguish between cognitive and somatic dimensions of anxiety), also presenting good psychometric indicators and highlighted as being an assessment tool capable of assisting in the planning of intervention strategies within the sports context, we aimed to perform a cross-cultural adaptation of the SAS-2 for use in Brazil.

\section{Method}

The process of cross-cultural adaptation started by obtaining permission from the main author of the original scale, Dr. Ronald Smith. The process was based on the stages proposed by Beaton et al., ${ }^{14}$ namely, translation, synthesis of versions, back-translation, peer revision, and pretest.

The original scale was translated into Brazilian Portuguese on an independent basis by three Brazilian professionals with fluency in English, namely, a language teacher with no experience in the topic, a sports psychologist, and a psychiatrist with experience in anxiety and assessment scales for signs and symptoms.

Next, a synthesis version of the three preliminary translations was produced to solve discrepancies and to select terms considered to be most adequate to the Brazilian context. The authors of the present study undertook this stage because of their knowledge and previous experience in the area of anxiety and psychiatric assessment scales.

Back-translation of the synthesis version was then performed by a Brazilian bilingual psychologist with experience in psychopathology and assessment scales. The back-translated version was sent to the main author of the original scale for appreciation.

Analysis of conceptual, semantic, idiomatic, and cultural equivalence of the scale was conducted by an expert committee comprised of five university professors in the areas of psychology, psychiatry, and physical education with broad experience in psychometry and/ or sports psychology (Supplementary Table 1 ).

The following aspects were analyzed by the experts in each analysis: for conceptual equivalence, whether the terms used actually represented the same original concept; for semantic equivalence, whether the terms had the same meaning in both the original and translated versions; for idiomatic equivalence, whether the denotative and literal meanings of the terms/expressions used corresponded, or had the same 
meaning, as those used in the original scale; finally, experimental or cultural equivalence was assessed according to the coherence and compatibility of the terms with the Brazilian cultural context. ${ }^{14,15}$

Analyses were performed on an independent basis and documented on an evaluation form developed for the present study. The experts were instructed to score each item according to the following scale: $-1=$ not equivalent; $0=$ not possible to evaluate/don't know; and $+1=$ equivalent. Next, percentage concordance was calculated by dividing the number of concordant experts by the total number of experts, the result being multiplied by 100 . Indices $\geq 80$ percent were considered satisfactory. ${ }^{15}$ In the end of this process, the authors prepared a consensus version.

The pretest consisted of interviews with 25 athletes conveniently selected for assessment of their general understanding of the items of the consensus version. Each participant signed the informed consent form and was then asked to read and paraphrase the instructions, items and response options of the scale, with relevant comments being recorded.

\section{Ethical aspects}

This study was approved by the local research ethics committee (protocol no. 17533/2015) according to the Resolution no. 466/2012 of the National Health Council for human research.

\section{Results}

The three first stages of the cross-cultural adaptation process of SAS-2 were followed as described above, including approval by the main author of the original scale. The majority of the items assessed for different types of equivalence presented satisfactory concordance percentages ( $\geq 80 \%$ ), as shown in Table 1 .

The recommendations given by the experts regarding each item of the synthesis version, mainly those with median concordance percentages, were analyzed and evaluated within the Brazilian context in terms of sports and language.

Therefore, in the synthesis version, in the instrument completing instructions, thewords "encontros, "'verdadeiro,"

Table 1 - Percentage of concordance between experts for equivalence assessment of the Brazilian version of the Sport Anxiety Scale-2

$$
(n=5)
$$

\begin{tabular}{|c|c|c|c|c|c|c|c|c|c|c|}
\hline \multirow{3}{*}{ Structure evaluated } & \multicolumn{10}{|c|}{ Equivalence } \\
\hline & \multicolumn{2}{|c|}{ Semantic } & \multicolumn{2}{|c|}{ Idiomatic } & \multicolumn{2}{|c|}{ Cultural } & \multicolumn{2}{|c|}{ Conceptual } & \multicolumn{2}{|c|}{ Mean } \\
\hline & $\mathbf{n}$ & $\%$ & $\mathbf{n}$ & $\%$ & $\mathbf{n}$ & $\%$ & $\mathbf{n}$ & $\%$ & $\mathbf{n}$ & $\%$ \\
\hline Title & 4 & 80 & 4 & 80 & 4 & 80 & 4 & 80 & 4.00 & 80 \\
\hline Subtitle & 5 & 100 & 5 & 100 & 5 & 100 & 5 & 100 & 5.00 & 100 \\
\hline Instruction & 3 & 60 & 3 & 60 & 4 & 80 & 3 & 60 & 3.25 & 65 \\
\hline Statement & 4 & 80 & 4 & 80 & 3 & 60 & 4 & 80 & 3.75 & 75 \\
\hline Item 1 & 4 & 80 & 5 & 100 & 5 & 100 & 4 & 80 & 4.50 & 90 \\
\hline Item 2 & 4 & 80 & 5 & 100 & 5 & 100 & 4 & 80 & 4.50 & 90 \\
\hline Item 3 & 3 & 60 & 4 & 80 & 5 & 100 & 4 & 80 & 4.00 & 80 \\
\hline Item 4 & 2 & 40 & 2 & 40 & 4 & 80 & 2 & 40 & 2.50 & 50 \\
\hline Item 5 & 3 & 60 & 3 & 60 & 4 & 80 & 3 & 60 & 3.25 & 65 \\
\hline Item 6 & 4 & 80 & 3 & 60 & 3 & 60 & 3 & 60 & 3.25 & 65 \\
\hline Item 7 & 5 & 100 & 5 & 100 & 5 & 100 & 4 & 80 & 4.75 & 95 \\
\hline Item 8 & 2 & 40 & 3 & 60 & 4 & 80 & 3 & 60 & 3.00 & 60 \\
\hline Item 9 & 3 & 60 & 4 & 80 & 5 & 100 & 4 & 80 & 4.00 & 80 \\
\hline Item 10 & 4 & 80 & 4 & 80 & 4 & 80 & 4 & 80 & 4.00 & 80 \\
\hline Item 11 & 3 & 60 & 2 & 40 & 3 & 60 & 4 & 80 & 3.00 & 60 \\
\hline Item 12 & 3 & 60 & 5 & 100 & 5 & 100 & 5 & 100 & 4.50 & 90 \\
\hline Item 13 & 5 & 100 & 5 & 100 & 5 & 100 & 4 & 80 & 4.75 & 95 \\
\hline Item 14 & 3 & 60 & 3 & 60 & 3 & 60 & 4 & 80 & 3.25 & 65 \\
\hline Item 15 & 4 & 80 & 5 & 100 & 5 & 100 & 5 & 100 & 4.75 & 95 \\
\hline Answer option 1 & 5 & 100 & 5 & 100 & 5 & 100 & 5 & 100 & 5.00 & 100 \\
\hline Answer option 2 & 5 & 100 & 5 & 100 & 5 & 100 & 5 & 100 & 5.00 & 100 \\
\hline Answer option 3 & 4 & 80 & 5 & 100 & 5 & 100 & 5 & 100 & 4.75 & 95 \\
\hline Answer option 4 & 5 & 100 & 5 & 100 & 5 & 100 & 5 & 100 & 5.00 & 100 \\
\hline Equivalence mean & 3.8 & 75.7 & 4.1 & 81.7 & 4.4 & 87.8 & 4.0 & 80.9 & - & - \\
\hline Scale mean & - & - & - & - & - & - & - & - & 4.1 & 81.5 \\
\hline
\end{tabular}

$\mathrm{n}=$ number of experts who considered the item equivalent in the synthesis and in the original version; \% = percentage concordance. 
"diz," and "jogos" were replaced with "torneios," "sincero," "representa," and "competições," respectively, according to the suggestions by the experts.

In the statement preceding the scale items, we accepted the experts' suggestions to replace the original sentence "Antes ou enquanto estou competindo em esportes" with "Antes ou enquanto estou competindo" as the expression "competindo em esportes" is not usually employed in the Brazilian culture.

Another modification involved items \#1, \#3, \#7, $\# 11$, and \#13. Because in Brazilian Portuguese the words "jogo/jogar" do not encompass the practice of certain sports modalities, e.g., judo, swimming, and gymnastics, among others, they were replaced with "competição/competir." For the same reason, the verb "jogar" was replaced with "fazer" in item \#8, whereas the word "atuar" was added in item \#9.

In item \#4, which showed the lowest concordance percentage, the expression "estou querendo fazer" was changed to "devo fazer," because, according to four experts, the translation of the expression "supposed to do" refers to the expectation of what one should do rather than with what is actually done. As for item \#13, the verb "pensar" was changed to "raciocinar," which better corresponds to the action of planning.

In order to increase idiomatic equivalence in item \#6, the word "desconforto" was added to the expression "tensão no estômago," while in item \#11, the sentence "Eu fico preocupado que eu possa me atrapalhar durante o jogo" was changed to "Eu fico preocupado em me atrapalhar durante a competição."

After analyzing all the recommendations given by the experts, the consensus version prepared by the authors was submitted to a pretest with a sample of 25 local athletes. These athletes were mostly male ( $72 \%)$ with ages ranging from 13 to 79 years (mean = $32.16 \pm 18.89$ years) and $>9$ years of formal education (75\%). They were essentially amateurs (92\%) and most performed collective sports (56\%), with basketball, baseball, running, handball, karate, swimming, muay thai, water polo, and volleyball being the most common modalities (Supplementary Table 2).

In the pretest, participants showed no sign of discomfort and/or lack of motivation during the completion of the scale. No problem was found in the comprehension of the terms used in the scale to describe anxiety symptoms, except the expression "estômago embrulhado," which was understood by one of the participants as "diarreia" while others referred to it as "ânsia," "azia," "enjoo," or "náusea." The majority of the athletes had a similar understanding of this item, and therefore no adjustment or insertion of examples was considered necessary.
Overall, the consensus version was understood and linguistically and culturally well accepted by the athletes, although a few adjustments to the layout of the scale were necessary to make reading and completion of the instrument easier. The Brazilian version of the SAS-2, named Escala de Ansiedade Esportiva-2, was considered by the main author of the original scale as an official version in Brazilian Portuguese language, and is now available to be evaluated for its psychometric quality, seeking evidence of validity and reliability. The Brazilian version of the SAS-2 is free and is available in Supplementary Figure 1.

\section{Discussion}

The present study aimed to perform the crosscultural adaptation of the SAS-2 for the Brazilian context. Among different possibilities, we chose to follow the stages proposed by Beaton et al., ${ }^{14}$ as this approach not only contemplates the steps established in the literature but is also one of the most widely used in the health setting.

We sought to form a team of translators with different academic backgrounds to increase the likelihood of using terms more compatible with the general population, i.e., avoiding technical and specific medical words. Notwithstanding, academic formation and experience in psychiatry and sports psychology were indispensable in preserving the characteristics that are inherent to the target population.

The committee of experts consisted of bilingual professionals with expertise in psychometry and knowledge of the construct assessed by the instrument, according to literature recommendations. ${ }^{14-16}$ The suggestions given by the experts were rigorously analyzed, and they were fundamental for the refinement of the Brazilian version of SAS- 2 .

In order to extend the use of the scale to a national basis, we took care not to include slangs or jargons that might make comprehension difficult, as Brazil is a very large country with diversified regional characteristics. The pretest demonstrated that the Brazilian version of the SAS-2 was understood by all athletes, regardless of gender, age (except up to 12 years old), education level, and sports modality.

Performing a cross-cultural adaptation process with well-defined steps and supported by theoretical references strengthens the field of psychometrics. The SAS- 2 has been adapted to the Brazilian context both linguistically and semantically, presenting the indispensable conditions for a survey of psychometric evidence. 


\section{Acknowledgements}

The authors would like to thank Maria Helena Peti de Oliveira, Fernanda Tartalha do Nascimento, and Marcos Hortes Nisihara Chagas for their translations, and João Paulo Machado de Sousa for the backtranslation. The authors are also grateful to the expert committee members Cristiano Roque Antunes Barreira, Flávio Rebustini, Gislane Ferreira de Melo, José Alexandre de Souza Crippa, and Sonia Regina Pasian. Finally, a sincere thanks to Fundação de Amparo à Pesquisa do Estado de São Paulo (FAPESP) (process no. 2015/24604-8) for the financial support granted to the study.

\section{Disclosure}

No conflicts of interest declared concerning the publication of this article.

\section{References}

1. Martens R. Sport Competition Anxiety Test. Champaign: Human Kinetics; 1977

2. Guzmán JIN, Amar JR, Ferreras CG. Ansiedad pré-competitiva y conductas de autocontrol en jugadores de futbol. Rev Psicol Deport. 1995;7:7-17.

3. De Rose Júnior $D$ Sato $C T$, Selingardi D Bettencourt EL Barros JCTS, Ferreira MCM. Situações de jogo como fonte de "stress" em modalidades esportivas coletivas. Rev Bras Educ Fis Esp. 2004; 18:385-95.

4. Santos AR, Lofrano-Prado MC, Moura PV, Silva EAPC, Leão ACC, Freitas CMSM. Ansiedade pré-competitiva em jovens atletas de nado sincronizado: uma análise à luz dos aspectos emocionais. Rev Educ Fis UEM. 2013;24:207-14.
5. Mesquita RM, Todt NS. A especialização esportiva precoce e a maturação biológica: investigando a base do olimpismo. Rev Perfil. 2000;4:83-7.

6. Martens R, Vealey RS, Burton D. Competitive anxiety in sport. Champaign: Human Kinetics; 1990.

7. Cox RH, Martens MP, Russel WD. Measuring anxiety in athletes: The revised Competitive State Anxiety Inventory-2. J Sport Exerc Psychol. 2003;25:519-33.

8. Smith RE, Smoll FL, Cumming SP, Grossbard JR. Measurement of multidimensional sport performance anxiety in children and adults: the Sport Anxiety Scale-2. J Sport Exerc Psychol. 2006;28:479-501.

9. Fernandes MG, Raposo-Vasconcelos J, Fernandes HM. Propriedades psicométricas do CSAI-2 em atletas brasileiros. Psicol Reflex Crit. 2012;25:679-87.

10. De Rose Júnior $D$. Influência do grau de ansiedade-traço no aproveitamento de lances-livres [dissertation]. São Paulo: Universidade de São Paulo; 1984.

11. Jannes CR, De Pelsemaeker D, De Deken D, Van Damme D. Psychometric properties of the Flemish version of the Sport Anxiety Scale-2. 13th FEPSAC European Congress of Sport Psychology; 2011; Madeira.

12. Ramis $Y$, Torregrosa $M$, Viladrich $C$, Cruz ]. [Adaptation and validation of the Spanish version of the Sport Anxiety Scale SAS2 for young athletes]. Psicothema. 2010;22:1004-9.

13. Sousa C, Gomes M, Torregrosa M, Viladrich C, Cruz J. Psychometric properties of the MCSYS, AGSYS and SAS-2: preliminary validation into Portuguese. 13th FEPSAC European Congress of Sport Psychology; 2011; Madeira.

14. Beaton DE, Bombardier C, Guillemin F, Ferraz MB. Guidelines for the process of cross-cultural adaptation of self-report measures. SPINE. 2000;25:3186-91.

15. Alexandre NMC, Coluci MZO. Validade de conteúdo nos processos de construção e adaptação de instrumentos de medida. Cien Saude Colet. 2011;16:3061-8.

16. Borsa JC, Damásio BF, Bandeira DR. Adaptação e validação de instrumentos psicológicos entre culturas: algumas considerações. Paideia. 2012;22:423-32.

\section{Correspondence:}

Flávia de Lima Osório

Departamento de Neurociências e Ciências do Comportamento, Faculdade de Medicina de Ribeirão Preto, Universidade de São Paulo

Avenida dos Bandeirantes, 3900, Monte Alegre

14049-900 - Ribeirão Preto, SP - Brazil

Tel. : +55 (16) 3602-2703

E-mail: flaliosorio@ig.com.br 